\title{
Diplocraterion parallelum Torell, 1870, and other trace fossils from the Lower Triassic succession of the Drienok Nappe in the Western Carpathians, Slovakia
}

\author{
VLADIMÍR ŠIMO \& MÁRIO OLŠAVSKÝ
}

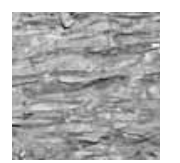

\begin{abstract}
Diplocraterion parallelum Torell, 1870, represents a significant element of the Lower Triassic ichnofossil associations in the Western Carpathians from the viewpoint of ichnofacies and stratigraphy. These assemblages of trace fossils commonly include $D$. parallelum, Arenicolites, Skolithos and a few of other trace fossils that rarely occur in isolated beds. Ichnological and sedimentological features (wavy and lenticular bedding, less frequently flaser bedding) correspond to the shallow water Skolithos ichnofacies in a restricted bay area. - Key words: Diplocraterion parallelum, Skolithos ichnofacies, wavy bedding, lenticular bedding, Lower Triassic, Western Carpathians, Slovakia.
\end{abstract}

S̆IMO, V. \& OLŠAVSKÝ, M. 2007. Diplocraterion parallelum Torell, 1870, and other trace fossils from the Lower Triassic succession of the Drienok Nappe in the Western Carpathians, Slovakia. Bulletin of Geosciences 82(2), 165-173 (10 figures). Czech Geological Survey, Prague. ISSN 1214-1119. Manuscript received November 2, 2006; accepted in revised form April 4, 2007; issued June 30, 2007. • DOI 10.3140/bull.geosci.2007.02.165

Vladimír Šimo, Slovak Academy of Sciences, Geological Institute, Dúbravská cesta 9, P.O.Box 106, 84005 Bratislava, Slovakia; vladosimo@yahoo.com・Mário Olšavský, State Geological Institute of Dionýz Štúr (ŠGÚDŠ), Kyncelovská 10, 97401 Banská Bystrica, Slovakia; olsavsky@gssrbb.sk

Diplocraterion, Skolithos and Arenicolites have not been reported from the Lower Triassic formations of the Western Carpathians until now. D. parallelum occurs in the Lower Triassic Vlkanová section (Fig. 1). The morphologically similar but ethologically different Rhizocorallium Zenker, 1836, trace fossil was described from the "Werfen Beds" near Silica (Roth 1939), from the "Campil" (Lower Triassic) marlstone and limestone near Kobeliarovo on the Silica Plateau (Šuf 1960), and from the Szin Formation in northern Hungary (Kovács et al. 1989).

The Lower Triassic sequences of the Western Carpathians are typified by clastic subarkoses, wackes and shales with carbonate content increasing upwards. Trace fossils mark boundaries of sequences in the Lower Triassic succession of the Drienok Nappe. In the sequence stratigraphy, assemblages of trace fossils (Diplocraterion, Arenicolites, Skolithos) often indicate transgressive and regressive surfaces (Dam 1990, Olóriz \& Rodríguez-Tovar 2000). On that count, the typical shallow-water trace fossil assemblages of the upper part of the Lower Triassic deposits in the Drienok Nappe support the sedimentological and palaeoenvironmental interpretation of a gradual transgression.

This paper presents the lithological and ichnological aspects of the palaeoenvironmental reconstruction of the Lower Triassic succession in the Vlkanová section.

\section{Geological setting}

The studied section crops out in a creek $2 \mathrm{~km}$ east of Vlkanová village (Fig. 1). The Diplocraterion isp. occurs there in a sequence, which is $c a 40 \mathrm{~m}$ thick, comprising the equivalent of the upper part of the Bodvaszilas Formation and of the lower part of the Szin Formation in the Vlkanová locality (Lower Triassic; Scythian; Fig. 2). The lower part of the section consists of arkose sandstones, and its middle and upper parts contain fine-grained sandstones to claystones with admixture of mica. In the uppermost part there are two laminated arkose sandstone beds of about $70 \mathrm{~cm}$ thickness. These sandstones are overlain with 5-30 cm thick limestone beds. The sequence represents the basal part of the Drienok Nappe, plausibly a relict of the Silica Nappe sensu lato (Polák et al. 2003, Olšavský 2004).

The Lower Triassic quartzitic subarkoses and wackes were typical and common facies in the Alpine-Carpathian area at that time. It was thought that they derived from the hypothetical "Vindelician Land" (Roniewicz 1966). The directions of palaeotransportation (not correlated by palaeomagnetism measurements) are from the north and north-west (Roniewicz 1966, Marschalko 1978). The Early Mesozoic position of the Central Carpathian block should be located to the southwest of the neighbouring Bohemian 


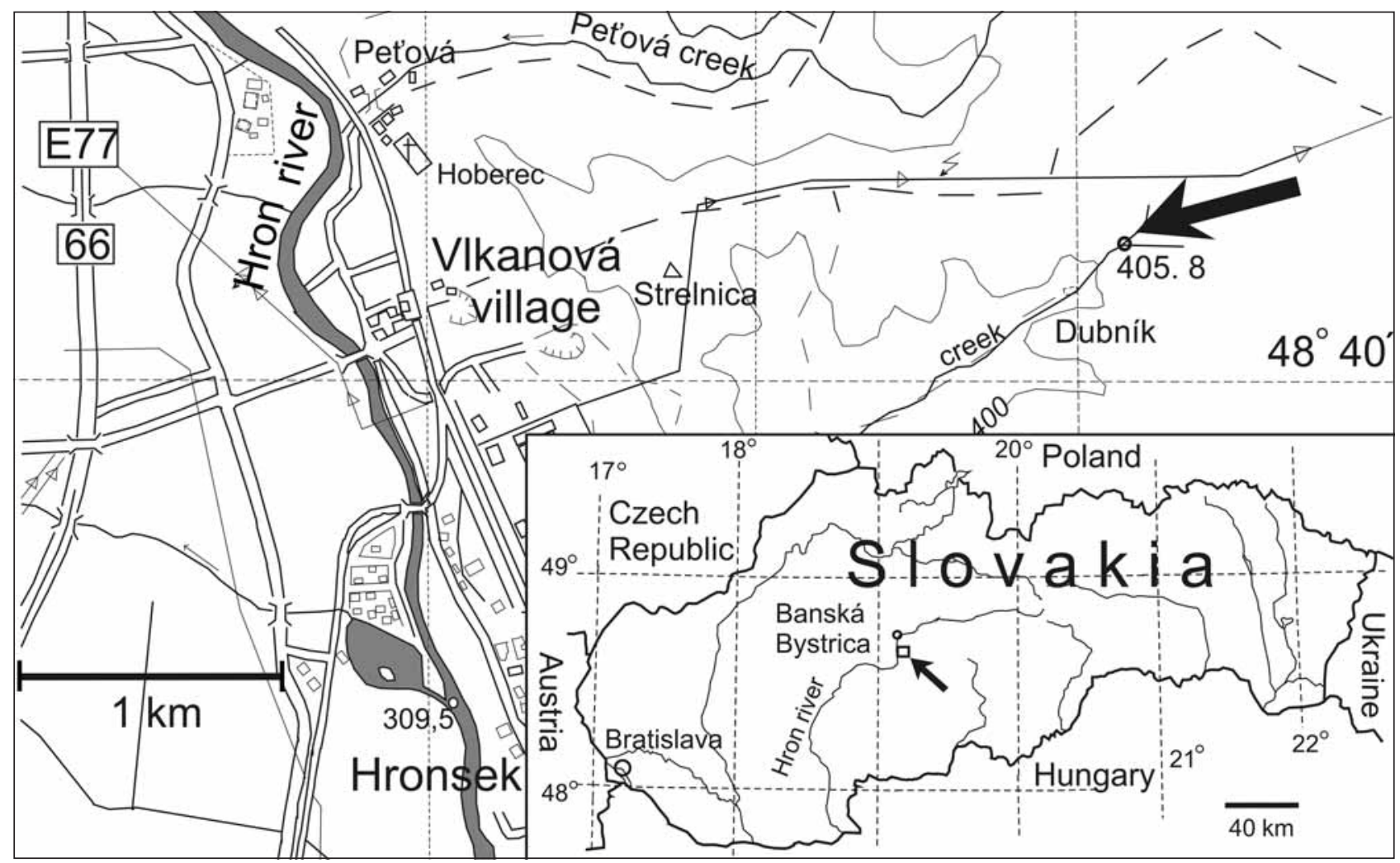

Figure 1. Location maps; the outcrop is situated in a creek $2 \mathrm{~km}$ east of Vlkanová village in the northern area of the Zvolen basin.

Massif (Michalík 1992). Terrigenous rocks deposited during the humid Early Triassic climatic event (e.g., Scythian) imply that individual palaeogeographic regions of the Western Carpathians were connected (Michalík 1994). The Lower Triassic facies of all the principal units (Tatricum, Fatricum, Hronicum, Zemplinicum) in the Western Carpathians have comparable sedimentological features. The Szin and the Bódvaszilas formations of the Silica Unit were defined by Kovács et al. (1989) and the Lúžna Formation (the Tatricum Unit; Fejdiová 1980) are coeval, similarly to the Benkovský potok Formation (the Hronicum Unit; Biely in Andrusov \& Samuel 1985) and to the Brezinka Formation (the Zemplinicum Unit; Grecula \& Együd 1982).

\section{Previous reports on ichnology}

Fejdiová $(1977,1980)$ reported non-determined trace fossils from the Lúžna Formation (Lower Triassic); Roth (1939), Šuf (1960) and Kovács et al. (1989) reported on Rhizocorallium Zenker, 1836, from the Lower Triassic formations of the Silica Unit; Olšavský (2004, Fig. 7) described the trace fossils of deposit feeders (?Planolites) from the Szin Formation. Olšavský \& Šimo (in press) presents the occurrence of Diplocraterion from the Lower
Triassic sequence of the Tatricum Unit in the Nízke Tatry Mts and from the Lower Triassic (the Benkovský potok Formation) of the Hronicum Unit on Nízke Tatry and Malé Karpaty Mts.

\section{Methods}

The morphology of some trace fossils was investigated in samples on orient cut and polished surfaces.

The degree of bioturbation was evaluated by the bioturbation index (BI - Taylor \& Goldring 1993). Using this method, the rate of bioturbation can easily be determined in the field. The bioturbation index BI is defined as follows: the 1-4\% content of bioturbated rock equals to BI-1, 5-30\% to BI-2, 31-60\% is BI-3, 61-90\% refers to $\mathrm{BI}-4,91-99 \%$ to $\mathrm{BI}-5$, and $100 \%$ is equal to BI-6.

Diplocraterion commonly shows a prevailing orientation to the bedding surfaces according to the current regime of the bottom (rheotactic orientation; Fillion \& Pickerill 1990). A statistical test of rheotactic orientation requires a considerable amount of field data. Theoretically, the samples desirable for statistical study of rheotactic orientation must contain a generation of trace fossils originated during one sedimentary event when ripple and current marks were 
formed. The available samples containing both trace fossils and current marks, however, could not be used for estimating relationships between the current regime and the activity of tracemakers due to missing current indicators. Therefore, the rheotactic orientation of Diplocraterion has not been proved.

\section{Systematic part}

\section{Arenicolites Salter, 1857}

Diagnosis. - Vertical U-tubes without spreite (Fürsich 1974b).

\section{Arenicolites isp.}

Figure 3

Material. - Several slabs with section fragments of tens of specimens.

Description. - Only fragments of cross section specimens were found. The limbs are parallel, the base of the Arenicolites was not found, the depths of U-tubes unpracticable to observe. Arenicolites limbs are 2 to $6 \mathrm{~mm}$ in diameter, the distance between the limbs is 2 to $30 \mathrm{~mm}$. Filling of burrows is arenaceous and easily distinguishable from surrounding fine-grained sediment. Trace fossil Arenicolites is without distinct wall.

Remarks. - Arenicolites is only associated with Diplocraterion. Systematic review of ichnogenus Arenicolites Salter, 1857, was provided by Häntzschel (1962) and by Fürsich (1974b). Arenicolites is characterized as a dwelling trace (Bromley 1996) and typically shallow marine trace fossil with several deep water instances (Bromley \& Asgaard 1979). The presence of paired apertures without spreite laminas could be related to Arenicolites isp.

\section{Diplocraterion Torell, 1870}

\section{Diplocraterion parallelum Torell, 1870}

Figures 4, 5, 6, 7B

Diagnosis. - U-tubes having parallel burrow arms and a unidirectional spreite (after Fürsich 1974a).

Material. - Tens of slabs with several specimens and three separate specimens are deposited in the Slovak National Museum (specimens catalogue numbers Z 24685; Z 2486; Z 24690).

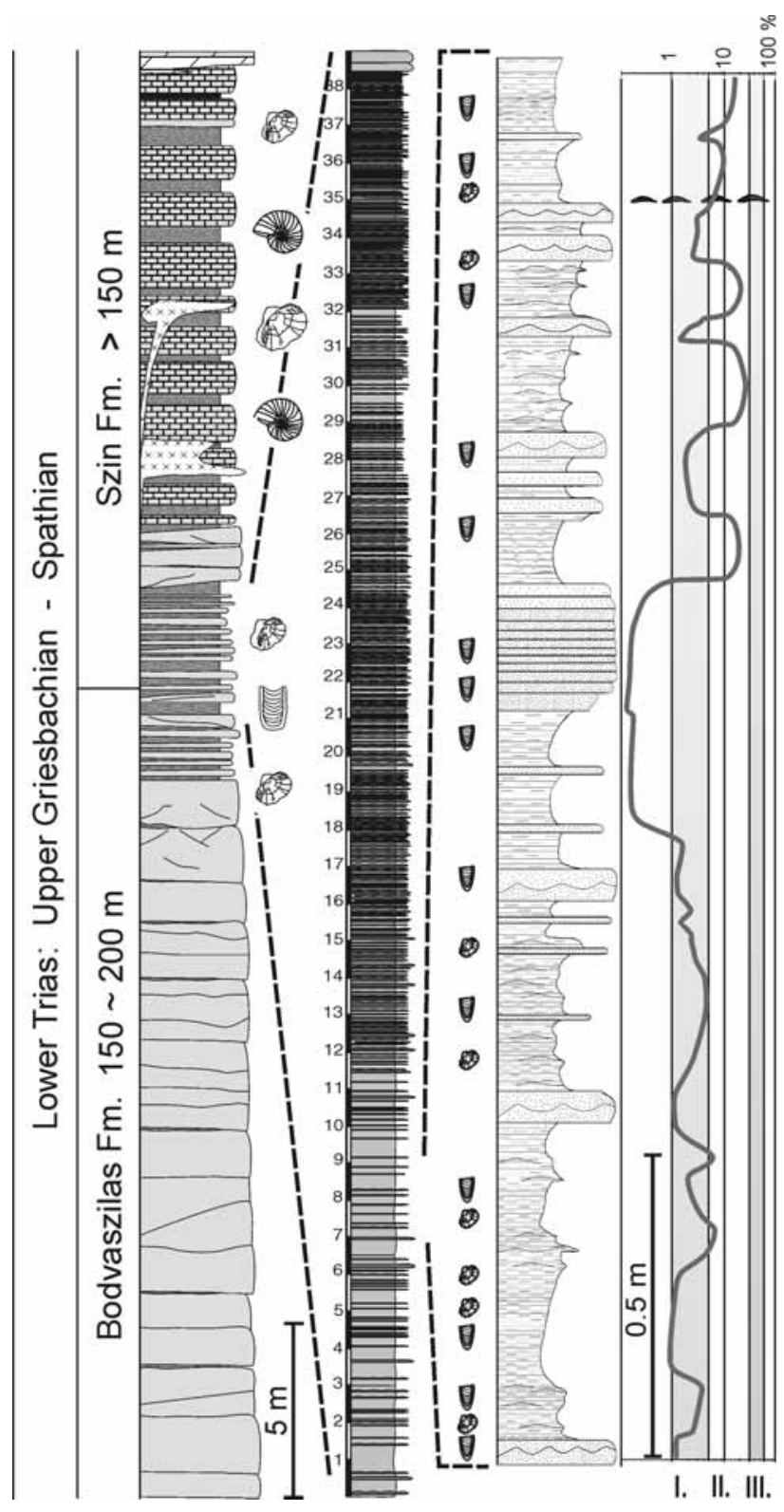

Figure 2. Basal part of the Drienok Nappe succession (left column); Vlkanová section (centre); detailed section with bioturbation indexes in the right columns: BI-1 (I) - first highlight grey collumn; BI-2 (II) - second white column; BI-3 (III) - third highlight grey column. The layer with internal moulds of molluscs in the upper part.

Description. - Diplocraterion from the Vlkanová site is usually seen in two dimensions on upper and lower bedding planes as dumbbell-shaped structures containing two circles as horizontal sections of the U-shaped limbs filled with sandstone, which are connected by spreite (Figs 4, 5). Diplocraterion also occurs as a part of full reliefs representing the basal part of the U-shaped limbs visible on the lower bedding plane as semicircular ridges plunging in the bed (Fig. 7B). Analogous epichnial furrows are locally seen when the U-shaped structure penetrates from the over- 

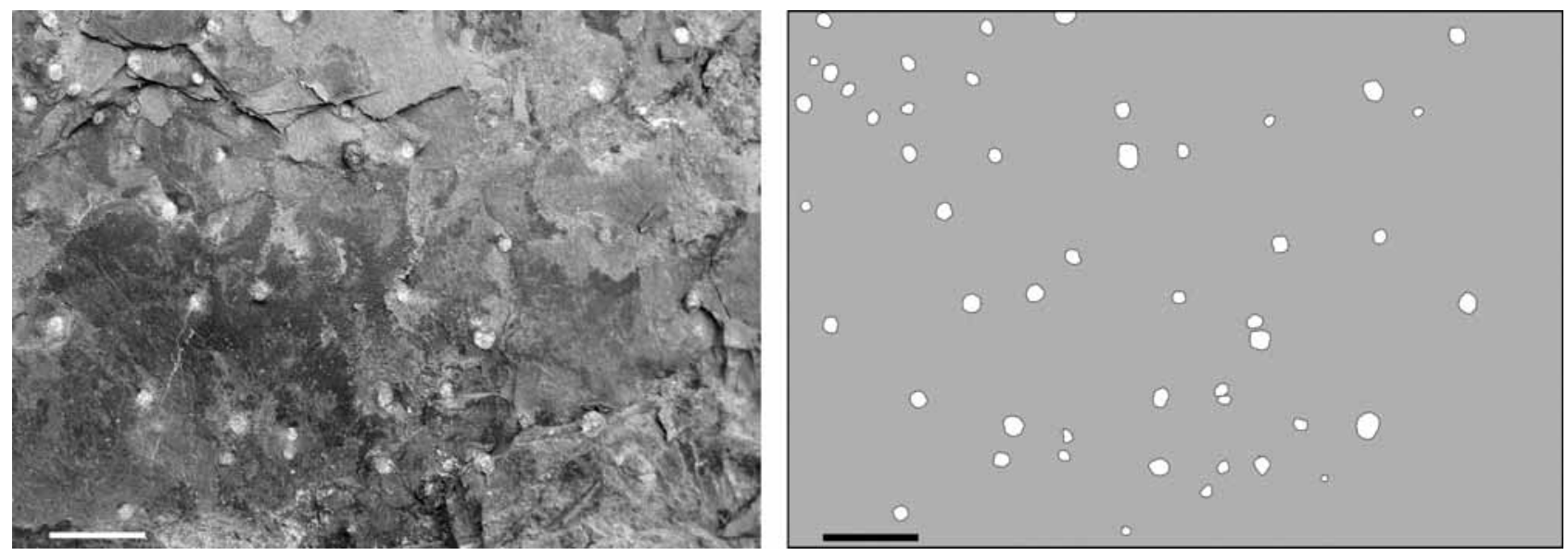

Figure 3. Arenicolites on the bedding plane. Scale bar is $2 \mathrm{~cm}$ long.

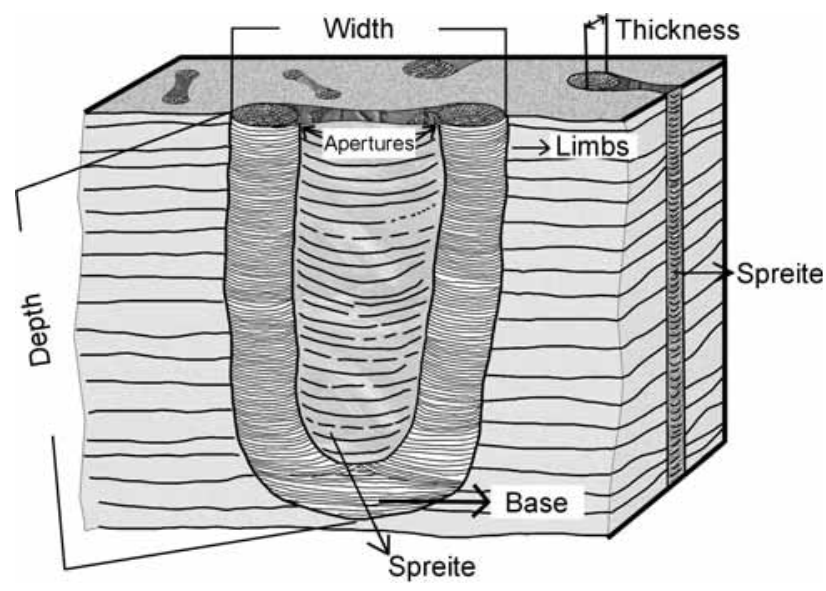

Figure 4. Idealized sketch of Diplocraterion, modified after Fürsich (1974a).

lying layer and the filling is removed. Spreite laminae in the cross section view are wider in proximity of the limbs (occasionally sediments of the laminae bordered the limb), and their middle part seems the thinnest one. The limbs are 1.5-6 $\mathrm{mm}$ in diameter (i.e. their thickness) and 5-50 mm apart (i.e. their width). The more complete vertical section of Diplocraterion, with two parallel limbs, can be rarely observed (Fig. 6). The depth of Diplocraterion is estimated at $10-13 \mathrm{~cm}$. Only protrusive spreiten structures have been recognized.

Remarks. - Diplocraterion most commonly occurs in red-coloured fine-grained sandstones with admixture of mica or in mudrock layers with thin sandstone lenses. In thicker layers ( $10 \mathrm{~cm}$ and more) of mudstones and sandstones, it is absent. Sandstone layers with ripple marks are usually $2-3 \mathrm{~cm}$ thick and they contain sparse ichnofossils. Diplocraterion scarcely occurs in reddish, monotonously coloured claystones.
Diplocraterion parallelum was erected by Torell, 1870 , from the Lower Cambrian of Sweden. Since then, several other names were proposed for vertical spreite-bearing U-tubes, e.g., Corophioides Smith, 1893, and Polyupsilon Howell, 1957. Fürsich (1974a) suggested these ichnogenera as synonyms of Diplocraterion Torell, 1870. Summary of Diplocraterion is provided by Fillion \& Pickerill (1990).

Diplocraterion is classified as a domichnial permanent dwelling structure (Bromley 1996) produced by suspension feeders or benthic predators (Fürsich 1975). It is also known as an "equilibrium structure" (e.g., D' Alessandro \& Bromley 1986; Bromley 1996) responding to sedimentation and erosion (yoyo-like behaviour by Goldring 1964). Limbs of Diplocraterion are perpendicular or subvertical in relation to the bedding plane (Fig. 4). The interval between the limbs is filled with unidirectional spreite, i.e. lamina of reworked sediment (Bromley 1996). Protrusive and retrusive spreite can be created as a result of (1) deposit-feeding, (2) growth of its inhabitant, (3) the impermeability of sediment and/or as a response to varying sedimentation or erosion (Fürsich 1974a). Bromley \& Hanken (1991) also have described Diplocraterion growth and protrusive structures from the Lower Cambrian sediments.

\section{?Skolithos Haldeman, 1840}

Figure 5

Diagnosis. - Single, vertical, unbranched burrows, cylindrical or subcylindrical (rarely prismatic where burrows are in contact), lined or unlined. Burrows perfectly straight to curved, and may be inclined to the vertical. It is $1-15 \mathrm{~mm}$ in diameter; its length varies, slightly along burrows, from a few centimetres up to one meter. Burrow wall distinct or indistinct, smooth to rough, may be annulated (after Alpert 1974). 

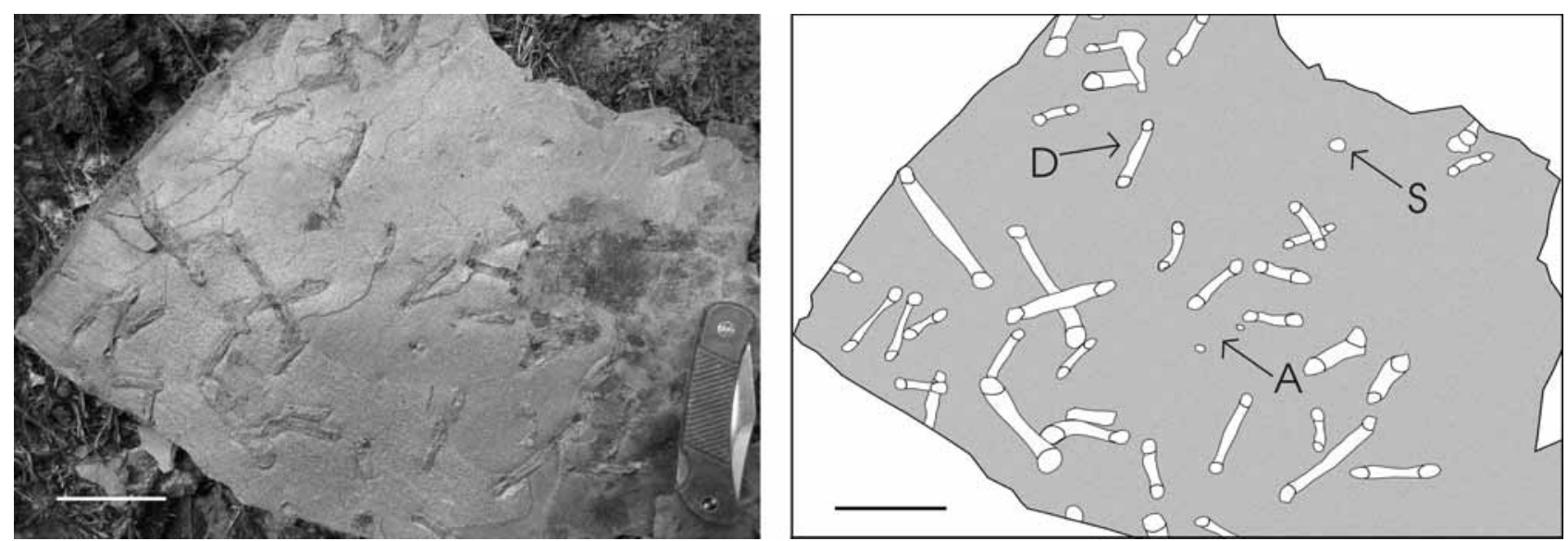

Figure 5. Diplocraterion on the upper bedding plane. - Abbreviations: D - Diplocraterion, A - Arenicolites, S - Skolithos. Scale bar is 4 cm long.
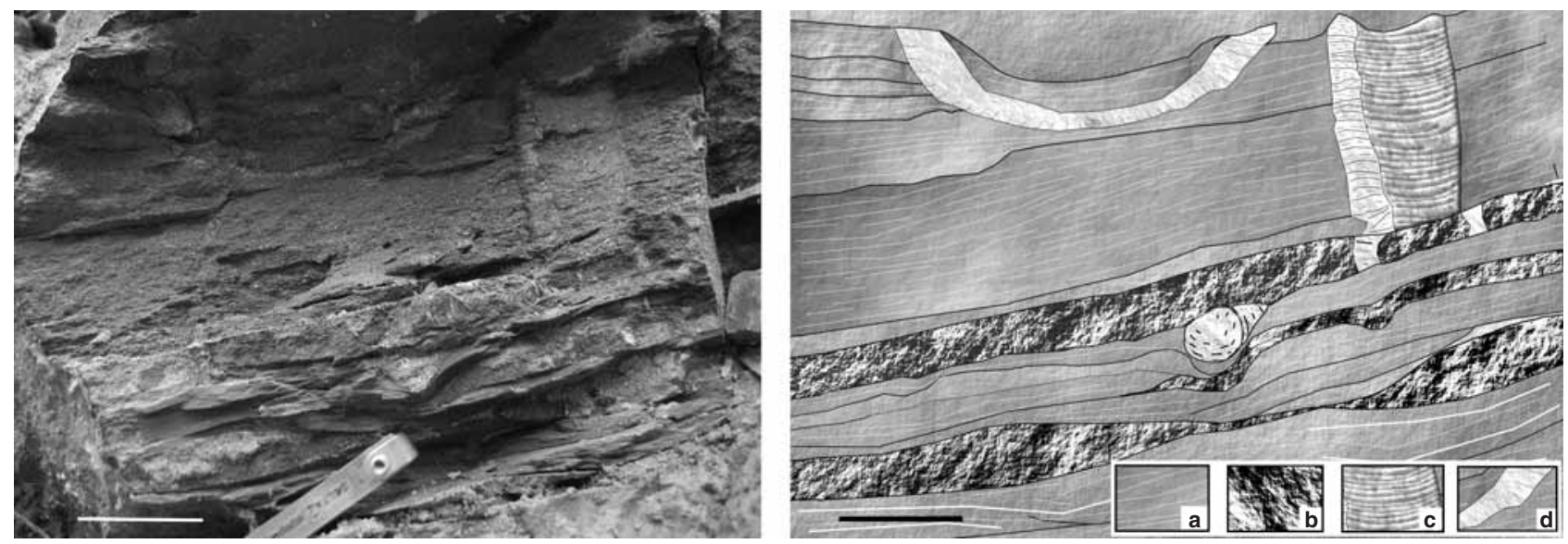

Figure 6. Diplocraterion in full relief. - Abbreviations: a - claystone, $\mathrm{b}$ - sandstone, $\mathrm{c}-$ spreite structure, $\mathrm{d}-\mathrm{burrow}$. Scale bars are $2 \mathrm{~cm}$ long.

Material. - Fragments of several specimens. A Skolithos specimen is located within the slab with several Diplocraterion specimens (deposited in the Slovak National Museum; No. Z 24685).

Description. - Filling of the trace fossil burrow is more coarse-grained then surrounding sediment, the trace fossil has indistinct wall of indeterminable length and $2-5 \mathrm{~mm}$ in diameter.

Remarks. - Skolithos proves to be rarer than Diplocraterion. Many findings described as Skolithos might represent only incomplete Arenicolites. Alpert (1974) published a systematic review of several ichnogenera and ichnospecies, and accepted five ichnospecies. However, in a year he recognized six ichnospecies within the former Skolithos (Alpert 1975). Fifteen years later, a systematics review was summarized by Fillion \& Pickerill 1990.

Skolithos scarcely occurs in the Diplocraterion and Arenicolites association. It is not excluded that this rare trace fossil represents the incomplete Arenicolites.

\section{Form A}

Figures $7 \mathrm{~A}, 8$

Material. - Cross section of two specimens (catalogue number Z 24687) and a slab with several tens of specimens deposited in the Slovak National Museum in Bratislava; No. Z 24688.

Description. - Narrow hypichnial crest, slightly curved, triangular in cross section, 5-18 mm long, 1-6 mm wide (at the widest crest point). In the cross section, a wide U-shaped structure preserved in full relief is visible (Fig. 8A). The U-shaped limbs are terminated by laminae. Maximum density of its occurrence is 46 specimens per $169 \mathrm{~cm}^{2}$. Trace fossil configuration is evidently stochastic - it can be considered as the basal part of Diplocraterion parallelum (Fig. 8). The triangular cross section of the limb, however, is untypical of Diplocraterion. The same trace fossil occurs in the same stratigraphical position of the Drienok Nappe at Chmelín (Olšavský 2004, Fig. 6). Its origin and ichnotaxonomy is obscure. It occurs 

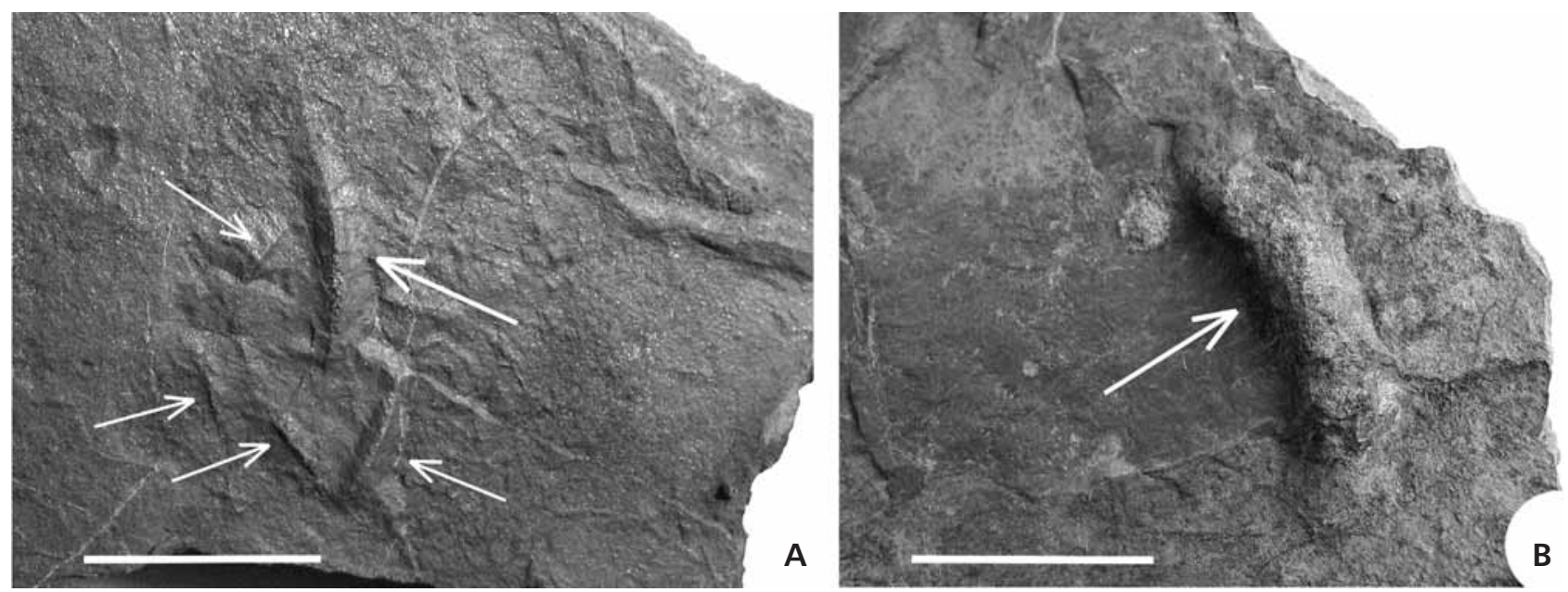

Figure 7. Two types of hypichnial trace fossils. $\bullet$ A - undetermined hypichnial crest. $\bullet$ B - base of Diplocraterion. Scale bars are $2 \mathrm{~cm}$ long.
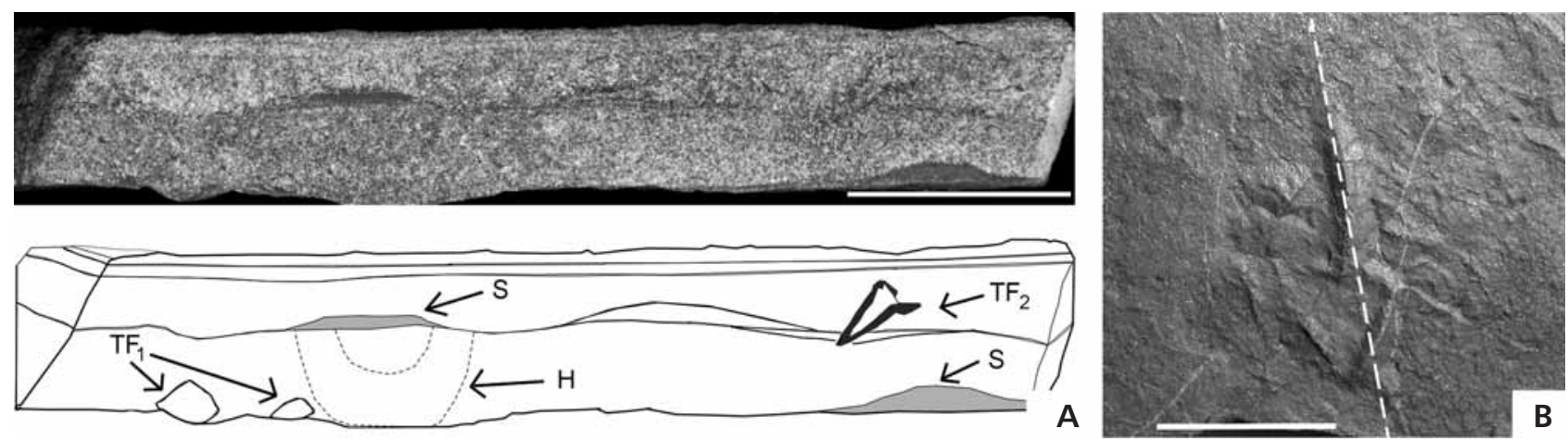

Figure 8. Section of the hypichnial crest. $\bullet$ A - vertical section of a bed. Abbreviations: $\mathrm{TF}_{1}-$ perpendicular section of crest, $\mathrm{TF}_{2}-\mathrm{dark}_{\mathrm{wall}}$ of an unidentified trace fossil, $\mathrm{S}$ - internal moulds on condensation surfaces, $\mathrm{H}$ - bioturbated indication of U-structure. $\bullet \mathrm{B}-$ lower bedding plane with the crest. Scale bars are $2 \mathrm{~cm}$ long.

rather frequently in the upper part of the Vlkanová section.

\section{Form B}

Figure 9

Material. - One specimen deposited in the Slovak National Museum in Bratislava; No. Z 24689.

Description. - Cylindrical trace fossil without wall, obliquely oriented in relation to a bedding plane, $20 \mathrm{~mm}$ in diameter. Its lateral side is penetrated with other shaft, which attains $10 \mathrm{~mm}$ in diameter.

\section{Discussion}

Heterolithic sediments, typified mainly by wavy and lenticular bedding, and less frequent flaser bedding (Fig. 10) prevail in the whole section. The wavy bedding is characte- rized by thin ripple cross-laminated sandstones alternating with mudrock in nearly equal proportions. Cross stratification, horizontal lamination, or small-scale hummocky cross stratification are present but rare. Formation of the flaser and wavy bedding requires two different flow regimes or fluctuating flows: the first one moves sand and creates ripples, the mud is deposited from suspension onto the rippled sand under the second regime. Subsequent rapid flow removes the mud from the ripples crests and the mud is preserved in the troughs or mudstone intraclasts. Flaser and wavy bedding are conventionally thought to be formed in tidal flat environments (Reineck \& Wunderlich 1968). Repeated thin alternation between sand and mud deposition is common on tidal flats, shallow subtidal environments, and delta front settings (Boggs 1987). These facies are interpreted as having a strong tidal signature characterized by fluctuating velocity and current reversals. Wavy bedding is commonly formed in environments where the energy alternates frequently from higher to lower values (mixed flats); lenticular bedding is commonly formed in relatively low energy environments (mud flats). Domi- 

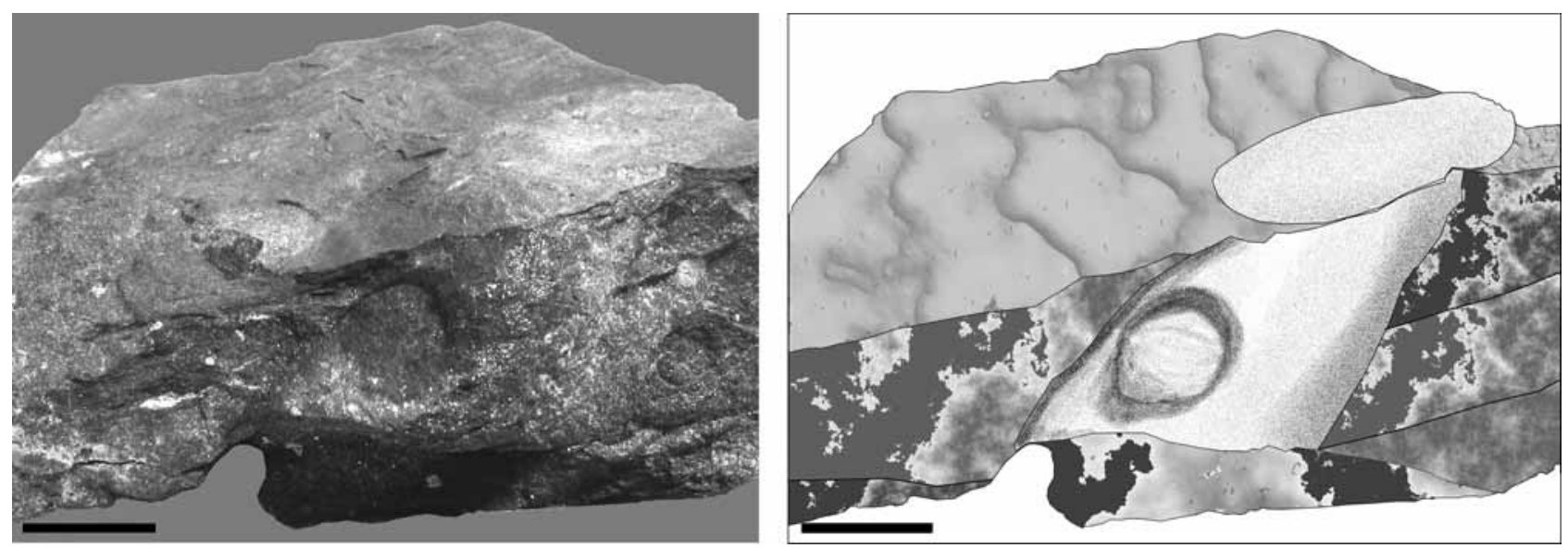

Figure 9. Cylindrical burrow, $20 \mathrm{~mm}$ in diameter, slanted in relation to the bedding plane. Smaller circular opening $10 \mathrm{~mm}$ in diameter is located in the burrow. Scale bar is $1 \mathrm{~cm}$ long.

nance of wave-generated ripple lamination is typical of wave-dominated sand flats, estuarine shorefaces, spits, siliciclastic ramps. Rhythmical alternation of muds and sands is also controlled by climatic changes; sands were preferentially deposited during humid periods ( $c f$. Michalík 1994).

From a large amount of bivalves collected in the studied locality, genera Myophoria and Anodontophora were identified. Both of them occur unevenly, being usually concentrated in thin layers of internal moulds. The shell layers often indicate erosional sequence boundary (Michalík et al. 1999; see Fig. 8). Preservation of shells was heavily influenced by condensation and it cannot be excluded that there were more taxa, which are missing due to this effect. According to the sedimentological situation (gradual fining upward trend) of the sequence, it is more probable that condensation surfaces are evidences of transgression.

The basal part of the Vlkanová section (Fig. 2) is characterized by the bioturbation index BI-2. Maximum content of reworked sedimentary rock was estimated as $11 \%$ in two detailed logs in the lower part of the section (Fig. 2). The highest BI-3 (31-60\% contribution of bioturbated sediment) was observed only in some layers in the uppermost part of the section. The bioturbation index is highest in rhythmically alternating thin $(2-25 \mathrm{~mm})$ sandstone and claystone layers. Ichnodiversity is low for the whole investigated section, which was caused by shallow brackish water conditions. Ichnofabric, i.e. all aspects of texture and internal structure of the sediment that result from bioturbation (Ekdale \& Bromley 1983) is mostly monospecific in the Vlkanová succession and being mostly confined to the Diplocraterion parallelum ichnofabric.

The occurrence of $D$. parallelum is most typical of the Skolithos ichnofacies (Frey \& Pemberton 1984). Eustatic changes of sea level and tidal activity, shallow water envi- ronment conditions, looseground to firmground substrate are characteristic environmental conditions for producers of Diplocraterion and other similar U-shaped and vertical trace fossils.

A comparable lithology and trace fossil assemblage (Diplocraterion, Arenicolites, Rhizocorallium) were described from the Lower Triassic tidal deposits of Svalbard (Gaździcki \& Trammer 1978). Diplocraterion ichnofabrics are typical of intertidal shallow water environments (Fürsich 1974a).

It can be summarized that a trace fossil assemblage dominated by Diplocraterion parallelum and other vertical trace fossils is typical of the whole studied Vlkanová section. Size variability of trace fossils (Diplocraterion limbs are $1.5-6 \mathrm{~mm}$ in diameter and 5-50 $\mathrm{mm}$ apart) could have been influence by salinity (Gingras et al. 1999). The maximum depth of the ichnofossils in the sediment is difficult to estimate because they are probably truncated during numerous episodes of non-sedimentation and erosion.

The studied trace fossils should be attributed to opportunistic trophic generalists (Vossler \& Pemberton 1988). The abundance of Diplocraterion fluctuates in the section (Fig. 2). Ichnological and lithological features correspond to the model of restricted-bay intertidal ichnofaunas (Mángano \& Buatois 2004).

Dam (1990) interpreted dense occurrences of D. parallelum as omission suites at transgressive surfaces. Olóriz \& Rodríguez-Tovar (2000) stated that D. parallelum might be an indicator of transgressive and regressive pulses. Obviously, the presence of $D$. parallelum was not influenced only by the relative sea-level changes. Occurrences of D. parallelum depended on numerous factors such as unconsolidated substrate, preservational potential or different energetic conditions (Fürsich 1975, Gibert \& Martinell 1998). 

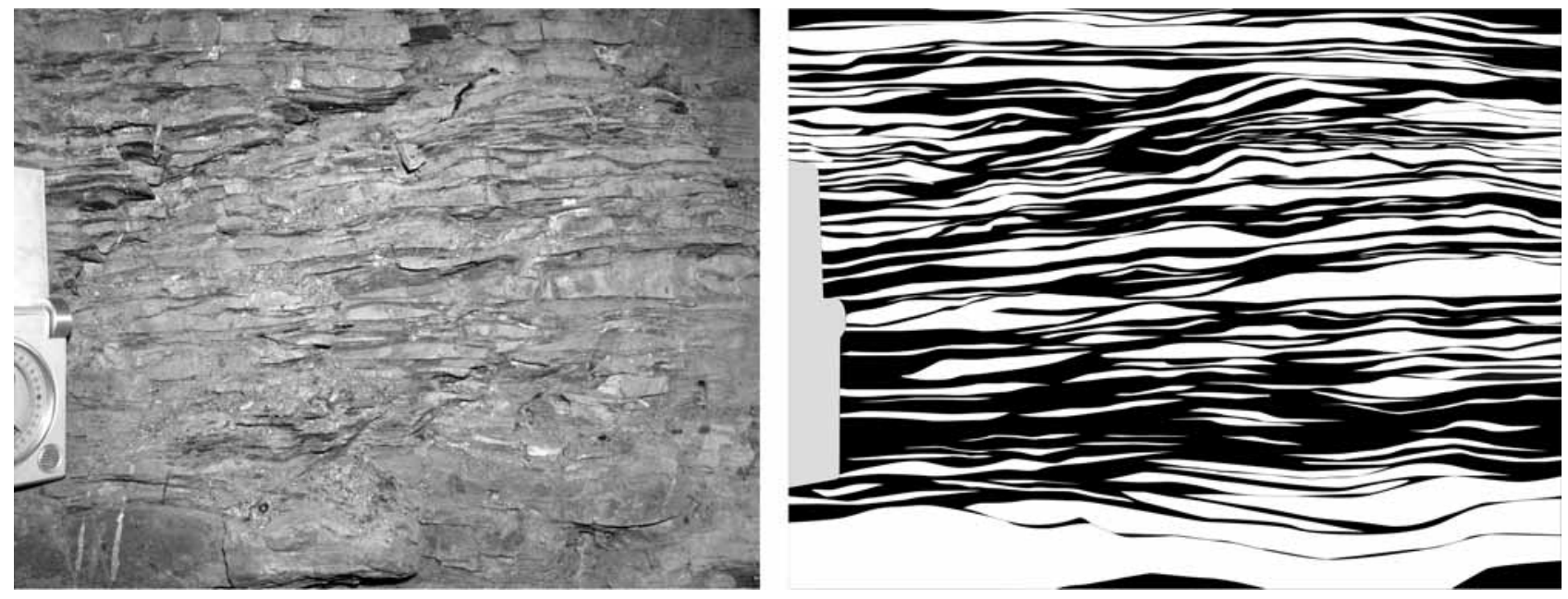

Figure 10. Wavy and lenticular bedding; dark layers represent claystones, white layers are for sandstone.

\section{Conclusions}

1. Diplocraterion parallelum is preserved in three variants in the studied section: (a) two-dimensional transversal cross sections of the U-shaped structure with spreite seen on the upper and lower bedding planes (most common); (b) basal part of the U-shaped structure seen on the lower bedding planes, and (c) in full relief seen in vertical section of the beds.

2. Arenicolites isp. and Skolithos isp. have been occasionally found in association with Diplocraterion. Diplocraterion ichnofabric was determined, which was probably produced by opportunist infaunal communities.

3. Monotonous assemblages of Diplocraterion present in beds with ripple cross bedding and other sedimentological features are typical of the shallow water Skolithos ichnofacies, and are similar to restricted bay intertidal ichnofaunas.

4. Vertical trace fossils assemblage, condensed shell beds of internal moulds, fining upward sediment and heterolithic sediments determine a transgressive character of the succession, which conforms to the general development of the Lower Triassic sedimentary basins in the Western Carpathians.

\section{Acknowledgements}

The authors wish to thank the official reviewers Alfred Uchman, Radek Mikuláš and Jozef Michalík. The study was supported by the VEGA (Scientific Grant Agency of the Ministry of Education of the Slovak Republic and the Slovak Academy) No. 6026 and the APVV (Slovak Research and Development Agency) No. 51-011305 grant projects and project of the Ministry of Environment of the Slovak Republic No. 2798 (Geological map of the Slovak Republic in scale $1: 200$ 000).

\section{References}

Andrusov, D. \& SAmuel, O. (eds) 1985. Stratigrafický slovník Západných Karpát, 2 (L-Z), 59-60. Geologický ústav Dionýza Štúra, Bratislava.

ALPERT, S.P. 1974. Systematic review of the genus Skolithos. Journal of Paleontology 48(4), 661-669.

ALPERT, S.P. 1975. Planolites and Skolithos from the Upper Precambrian-Lower Cambrian White-Inyo Mountains, California. Journal of Paleontology 49(3), 508-521.

Boggs, S. 1987. Principles of Sedimentology and Stratigraphy. 784 pp. Merrill Publishing Company, Columbus, Ohio.

Bromley, R.G. 1996. Trace Fossils, Biology, Taphonomy and Applications. 361 pp. Second edition, Chapman \& Hall.

Bromley, R.G. \& AsgaARD, U. 1979. Triassic freshwater ichnocoenoses from Carlsberg fjord, east Greenland. Palaeogeography, Palaeoclimatology, Palaeoecology 28, 39-80.

Bromley, R.G. \& HANKEN, N.M. 1991. The growth vector in trace fossils: examples from the Lower Cambrian of Norway. Ichnos 1, 261-276.

D'Alessandro, A. \& Bromley, R.G. 1986. Trace fossils in Pleistocene sandy deposits from Gravina area, southern Italy. Rivista Italiana Paleontologica e Stratigrafia 92(1), 67-102.

DAM, G. 1990. Palaeoenvironmental significance of trace fossils from the shallow marine Lower Jurassic Neill Klinter Formation, East Greenland. Palaeogeography, Palaeoclimatology, Palaeoecology 79, 221-248.

EkDALE, A.A. \& BROMLeY, R.G. 1983. Trace fossils and ichnofabrics in the Kjølby Gaard Marl, uppermost Cretaceous, Denmark. Bulletin of the Geological Society of Denmark 31, 107-119.

FEJDIOVÁ, O. 1977. Development of the Lower Triassic clastics in the central West Carpathians. Geologický zborník-Geologica Carpathica 28, 167-176.

FEJDIOVÁ, O. 1980. Lúžňanské súvrstvie - formálna spodnotriasová litostratigrafická jednotka. Geologické práce, Správy $74,95-101$.

Fillion, D. \& PickeriLl, R.K. 1990. Ichnology of the Upper Cambrian? to Lower Ordovician Bell Island and Wabana 
groups of eastern Newfounland, Canada. Palaeontographica Canadiana 7, 1-119.

Frey, R.W. \& PEMBERTON, S.G. 1984. Trace fossil facies models, 189-207. In WaLker, R.G. (ed.) Facies Models. Geological Association of Canada. Second edition.

FÜRSICH, F.T. 1974a. On Diplocraterion Torell 1870 and the significance of morphological features in vertical, spreiten-bearing, U-shaped trace fossils. Journal of Paleontology 48, 952-954.

FÜRSICH, F.T. 1974b. Corallian (Upper Jurassic) trace fossil from England and Normandy. Stuttgarter Beträge zur Naturkunde, Serie B 13, 1-51.

FÜRSICH, F.T. 1975. Trace fossils as environmental indicators in the Corallian of England and Normandy. Lethaia 8, 151-172.

GAŹDZICKI, A. \& TRAMmER, J. 1978. Tidal deposits in the Lower Triassic of Svalbard. Neues Jahrbuch für Geologie und Paläontologie, Monatshefte 6, 321-331.

Gibert, J. DE \& MARTinell, J. 1998. Ichnofabric analysis of the Pliocene marine sediments of the Var basin (Nice, SE France). Geobios 31, 271-281.

Gingras, M. K., Pemberton, S. G., Saunders, T. \& Clifton, H. E. 1999. The ichnology of Modern and Pleistocene brackish-water deposits at Willapa Bay, Washington: Variability in estuarine settings. Palaios 14, 352-374.

GolDRING, R. 1964. Trace fossils and the sedimentary surface in shallow water marine sediments. Developments in Sedimentology 1, 136-143.

GRECULA, P. \& EGYÜD, K. 1982. Litostratigrafia mladšieho paleozoika a spodného triasu Zemplínskych vrchov. Mineralia Slovaca 14, 221-239.

HÄNTZSCHEL, W. 1962. Trace Fossils and Problematica, W177-W245. In Moore, R.C. (ed.) Treatise on Invertebrate Palaeontology. Part W Miscellanea. Geological Society of America and University of Kansas Press, Kansas.

KovÁCs, S., LeSS, G., Piros, O., RÉTI, Z. \& Róth, L. 1989. Triassic formations of the Aggtelek - Rudabánya Mountains (Northeastern Hungary). Acta Geologica Hungarica 32, 31-36.

MÁngano, M.G. \& BuAtols, L.A. 2004. Ichnology of Carboniferous tide-influenced environments and tidal flat variability in the North American Midcontinent, 157-178. In MCILROY, D. (ed.) The Application of Ichnology to Palaeoenvironmental and Stratigraphic Analysis. Geological Society, London, Special Publications 228.

MARSCHALKO, R. 1978. Evolution of sedimentary basins and palaeotectonic reconstructions of the West Carpathians, 35-49.
In VOZÁR, J. (ed.) Palaeogeographical Evolution of the West Carpathians. State Geological Institute of Dionýz Štúr.

Michalík, J. 1992. Comments on the Mesozoic palinspastic interpretations of the Western Carpathians. Geologica Hungarica 35, 39-47.

MichALÍK, J. 1994. Notes on the palaeogeography and palaeotectonics of the Western Carpathian area during the Mesozoic. Mitteilungen. Österreichische Geologische Gesellschaft 86, 101-110.

Michalík, J., ReHÁKovÁ, D., KovÁč, M., SOTÁK, J. \& BARÁTH, I. 1999. Geológia stratigrafických sekvencií. Základy sekvenčnej stratigrafie. 234 pp. Vydavatel'stvo Slovenskej Akadémie vied, VEDA, Bratislava.

OlóRIZ, F. \& Rodríguez-TOvaR, J. 2000. Diplocraterion: A useful marker for sequence stratigraphy and correlation in the Kimmeridgian, Jurassic (Prebetic Zone, Betic Cordillera, southern Spain). Palaios 15, 546-552.

OLŠAVSKÝ, M. 2004. Position of the Drienok Nappe towards the underlying tectonic units and its Lower Triassic development. Mineralia Slovaca 36, 77-86.

OLŠAVSKÝ, M. \& ŠıMO, V. In press. Diplocraterion: výrazná ichnofaciálna črta spodného triasu Západných Karpát. Mineralia Slovaca 39(3).

Polák, M., Filo, I., Havrila, M., BezÁk, V., Kohút, M., Kováč, P., Vozár, J., Mello, J., Maglay, J., ElečKo, M., Olšavský, M., Pristaš, J., Siman, P., Buček, S., Hók, J., RAKús, M., LeXA, J. \& ŠImON, L. 2003. Geologická mapa Starohorských vrchov, Čiertaže a severnej časti Zvolenskej kotliny 1 : 50 000. Vydavatel'stvo Štátneho geologického ústavu Dionýza Štúra, Bratislava.

REINECK, H.E. \& WUNDERLICH, F. 1968. Classification and origin of flaser and lenticular bedding. Sedimentology 11, 99-104.

Roniewicz, P. 1966. Lower Werfenian (Seisian) deposits in the Tatra Mts. Acta Geologica Polonica 16, 1-90 (in Polish).

Roth, Z. 1939. Geologie okolí Silice u Rožňavy. Zprávy ČSAV, 1-21.

ŠUf, J. 1960. Nové poznámky ke geologii okolí Kobeliarova, S̆títniku a Nandráže na jižním Slovensku. Geologické práce, Zprávy 20, 111-126.

TAYLOR, A.M. \& GOLDRING, R. 1993. Description and analysis of bioturbation and ichnofabric. Journal of the Geological Society of London 150, 141-148.

Vossler, S.M. \& Pemberton, S.G. 1988. Skolithos in the Upper Cretaceous Cardium Formation: an ichnofossil example of opportunistic ecology. Lethaia 21, 351-362. 
